\title{
Evidence of an Indigenous Microbiota (Yeast) in the Dry Valleys of Antarctica
}

\author{
By H. S. VISHNIAC* AND W. P. HEMPFLING \\ Department of Biology, University of Rochester, River Station, Rochester, \\ New York 14627, U.S.A.
}

(Received 10 August 1978)

Soil samples from sites in the Dry Valleys of South Victoria Land, Antarctica, similar to some sites previously considered abiotic, contained a variety of microbes. The fungi recovered included Tilletiopsis washingtonensis, Sporobolomyces holsaticus, Sp. roseus (all previously unreported from Antarctica), Cryptococcus laurentii var. laurentii and $\mathrm{Cr}$. vishniacii, as well as some unremarkable filamentous fungi imperfecti. Cryptococcus vishniacii occurs only in these soils, has a distribution suggesting indigenous origin and shows appropriate psychrophilic character and energy requirements for life in this highly stressed environment. Populations of $\mathrm{Cr}$. vishniacii cloned and grown at $4{ }^{\circ} \mathrm{C}$ are heterogeneous in temperature response, some cells being capable of growth at $20^{\circ} \mathrm{C}$ or $23{ }^{\circ} \mathrm{C}$ with loss of the ability to assimilate succinate or citrate. Cryptococcus vishniacii and endolithic cyanobacteria could constitute a minimal community in Dry Valley soils.

\section{INTRODUCTION}

The soils of the Dry Valleys of South Victoria Land, Antarctica, are among the most stressed environments on earth (see Horowitz et al., 1972; Vishniac \& Mainzer, 1973). The mean annual air temperature is -20 to $-25^{\circ} \mathrm{C}$. Strong winds from the continent's interior move over the valleys, with relative humidity averaging around $10 \%$ (frequently below $5 \%$ ), causing sublimation of a snowfall which in any case amounts to only $15 \mathrm{~g} \mathrm{~cm}^{-2}$ year-1. Occasional localized melts of snow do occur in direct sunlight. The combination of low temperatures, very low water content and scarcity of organic material in the soil make this region inhospitable to life.

Macrobiota are absent; even the overflight of a skua is a rare event. Microbiota were considered to be absent from up to $24 \%$ of the soil samples examined by Horowitz et al. (1972). The majority of such sterile sites do not contain toxic compounds, suggesting that the absence of detectable bacteria, algae and fungi is due to climatic or other edaphic factors. The microbial populations detected are typically very small, in approximate proportion to the water content of soil samples. These and other observations (see Horowitz et al., 1972) suggested that the Dry Valleys are 'abiotic', i.e. do not contain an indigenous microbiota, and that micro-organisms found are airborne contaminants. There are no published studies of Dry Valley airspora; the recovery of microbes unable to grow at environmental temperatures and aerobiological studies of other regions make it obvious that Antarctica cannot be considered geographically isolated from any form of microbial life. Polar air masses have an airspora (see Gregory, 1973). Whether air transport results in an extension of range depends upon viability during transport and niche availability after deposition. Metabolic activity (as indicated by the liberation of ${ }^{14} \mathrm{CO}_{2}$ from ${ }^{14} \mathrm{C}$-labelled substrates) in sterile Antarctic soils has been attributed to the residual enzymic activity of

* Present address: Department of Cell, Molecular and Developmental Biology, Oklahoma State University, Stillwater, Oklahoma 74074, U.S.A. 
non-viable deposited airspora. The biotic portion of such an ecosystem would be a pseudocommunity, dependent for existence upon a continuous input of deposited airspora.

W. V. Vishniac (with S. E. Mainzer) visited the Wright, Odin and Perse Valleys during the austral summer of 1971-72 (Vishniac \& Mainzer, 1973) to re-examine their microbiota, returning (with Z. Bowen) in the austral spring of 1973 to obtain greater distribution of sampling sites in the Wright Valley and on Mount Baldr. Soil samples were aseptically collected (from 12 November 1973 onwards) for microbiological and chemical analysis, ${ }^{14} \mathrm{CO}_{2}$-release experiments were completed and slides were implanted in soil. Most of the slides were not recovered before premature termination of the expedition upon Dr Vishniac's accidental death on 10 December 1973.

Samples were returned to the University of Rochester, U.S.A., in early January 1974 through the kind offices of other investigators. They were not refrigerated during transit and may be presumed to have been subjected to temperatures well in excess of $20^{\circ} \mathrm{C}$. Soils were examined in this laboratory, and larger rocks in the laboratory of Dr E. I. Friedmann at Florida State University, for evidence of indigenous communities in the Dry Valley ecosystem. Friedmann \& Ocampo (1976) found endolithic cyanobacteria, capable of acting as primary producers.

Differentiation between isolates representing persistent communities and those of pseudocommunities requires a model based upon habitat characteristics in the Dry Valleys. The Dry Valleys are between $10^{4}$ and $10^{5}$ years old. In a highly stressed environment of an age which approaches infinity in microbial generation times, one may expect to find not simply desiccation-resistant psychrophiles, but unique taxons specifically adapted to survival and growth in our planet's coldest desert. The extremes of stress may be avoided in sheltered microhabitats near or on the soil surface, e.g. by endolithic growth. The greater variability of surface temperatures [Cameron (1974) observed that the surface of an insolated rock rose from -15 to $+27 \cdot 5^{\circ} \mathrm{C}$ in $3 \mathrm{~h}$ ] compared with air or subsurface temperatures may result in longer experience of optimal growth temperatures in such microhabitats. Endolithic growth would also prevent ready dispersal, sparing small populations the growth-depressing effects of further depletion (such as low $\mathrm{CO}_{2}$ partial pressures, see Pirt, 1975).

Low levels of abundance and diversity minimize interspecific competition but do not provide reliable supplies of fixed carbon, nitrogen and growth factors. An indigene must produce new cells at a rate sufficient for population survival using available levels of energy sources and available materials. Auxotrophy and the production of urease or extracellular proteases are not expected; the use of nitrate- $\mathrm{N}$ (typically abundant in desert soils) is expected. Nutritional versatility, suggested by the theoretical correlation of a poor resource base with broad range utilization (Pianka, 1976), is not always associated with occurrence in soil or water of low organic content: Sporobolomyces antarcticus (described from Lake Vanda sediment by Goto et al., 1969) utilizes more small molecules (20) than most yeasts, but Leucosporidium antarcticum, from equally or more depleted habitats, assimilates only one to ten substrates (Fell \& Phaff, 1971).

Communities of low abundance and diversity are often unstable under varying stress. Since a vacated site can only be recolonized by emigrants from the very small populations of the few indigenous taxa, one may expect recolonization to be random with respect to taxon. The survival of allochthonous species from the airspora will depend upon a survival constant which is a function of the severity of climatic-edaphic factors at a given site. Quantitative analysis of soil samples will reveal only the predominance of microbes originating in comparatively large extraterritorial population centres. An analysis of site distribution by taxon will differentiate adventitious species (greatest diversity at more favourable sites and no new records at more severe locations) and indigenes (random distribution).

A varied microbiota was isolated from the Dry Valley soil samples; we here report the identification and distribution of fungal isolates. Isolates of Cryptococcus vishniacii (Vishniac \& Hempfling, 1979) were further examined for congruence with the following characters 
predicted for a model indigene: unique species with random distribution in endolithic microhabitats, psychrophilic, xeroduric, urease and protease negative, nitrate positive, and growth factor independent.

\section{METHODS}

Soil analysis. Soil samples were collected for chemical analysis by placing several hundred grams into aluminum cans which were immediately hermetically sealed. Free water was measured gravimetrically by placing soil in heated, tared Pyrex weighing vials and heating for $48 \mathrm{~h}$ at $110^{\circ} \mathrm{C}$ in vacuo. Water extract of soil ( $5 \mathrm{~g}$ suspended in $10 \mathrm{ml}$ previously distilled water) was used to determine the $\mathrm{pH}$ value. Carbon and nitrogen were determined with a Hewlett-Packard $\mathrm{CHN}$ analyser; $\mathrm{K}^{+}, \mathrm{Na}^{+}, \mathrm{Ca}^{2+}$ and $\mathrm{Mg}^{2+}$ in aqueous extracts of the soils were determined with a Perkin-Elmer atomic absorption spectrophotometer; and inorganic phosphate was estimated by the method of Wahler \& Wollenberger (1958).

Method of isolation. Soil samples were collected for microbiological analysis by transferring 50 to $100 \mathrm{~g}$ with a sterile trowel to sterile polyethylene bags. These samples were held, upon reaching our laboratory, at 2 to $5{ }^{\circ} \mathrm{C}$ in a refrigerated room. Subsamples, aseptically removed at intervals up to 9 April 1975 , were subjected to isolation methods designed to enrich, rather than count, contained microbes and to compare the results of enrichment at temperatures representing those at which growth might occur in situ $\left(2\right.$ to $5{ }^{\circ} \mathrm{C}$, 10 to $12{ }^{\circ} \mathrm{C}, 15^{\circ} \mathrm{C}$ and room temperature of about $22^{\circ} \mathrm{C}$ ). Grinding under aseptic conditions and percolation (Lees \& Quastel, 1946) were used to encourage emergence of microbiota growing in the interstices of rock particles.

Soil particles were (i) placed directly on to heterotrophic medium [CAA medium: Difco Casamino acids $\left(0.1 \%\right.$, w/v) in a basal salts mixture of $\mathrm{MgSO}_{4} .7 \mathrm{H}_{2} \mathrm{O}\left(0.08 \%\right.$, w/v), $\mathrm{NH}_{4} \mathrm{Cl}(0.04 \%, \mathrm{w} / \mathrm{v}), \mathrm{NaCl}(0 \cdot 3 \%$, w/v) and Vishniac \& Santer's (1957) trace metal mix 1:10] and on to a medium suitable for the growth of nitrogen-fixing organisms [glucose $(5 \mathrm{mM})$, potassium phosphate buffer $(15 \mathrm{mM}) \mathrm{pH} \mathrm{7.0}$ and 1:10 basal salts without $\mathrm{NH}_{4} \mathrm{Cl}$, both solidified with $1.5 \%(\mathrm{w} / \mathrm{v})$ agarose, with or without a thin agar overlay to prevent surface drying; and (ii) placed, after aseptic grinding, on CAA, glucose $(5 \mathrm{~mm}) / \mathrm{salts} / \mathrm{phosphate}$ and $\mathrm{YCH}$ lyeast extract $(0.01 \%, w / v)$, casein hydrolysate $(0.1 \%, w / v)$, salts and phosphate buffer] media solidified with agarose.

Alternatively, subsamples were subjected to heterotrophic or autotrophic enrichment for various periods before separately plating portions of rock particles and the supernatant fractions. Heterotrophic enrichments included (i) suspension in CAA medium (with shaking) for 1 to $5 \mathrm{~h}$ or for periods of up to $10 \mathrm{~d}$ at $10^{\circ} \mathrm{C}$ and (ii) percolation with CAA medium for periods up to 1 month at various temperatures, before plating on one or more of the heterotrophic media listed above. Autotrophic enrichments included (i) exposing subsamples to light at $10^{\circ} \mathrm{C}$ for up to $46 \mathrm{~d}$ with plating on BG-11 (Wolk, 1973) and CAA media, (ii) percolation with Thiobacillus medium (Vishniac \& Santer, 1957), Nitrosomonas medium (Collins, 1969), Ferrobacillus medium (Vishniac \& Santer, 1957) and BG medium (Wolk, 1973) with illumination for up to 1 month at several temperatures and (iii) stationary incubation with media and gas mixtures (in air) appropriate for Hydrogenomonas and for methane-oxidizing bacteria (Vishniac \& Santer, 1957). Following autotrophic enrichment, both the enrichment medium and separated soil particles were placed on CAA medium (as well as on appropriate autotrophic media) in the hope that 'cascade' enrichment (the enrichment of heterotrophs supplied with carbon and energy by the prior growth of autotrophs) of unusual heterotrophs might have occurred.

Identificaton of fungal isolates. Literature on the identification of filamentous Fungi Imperfecti is accessible through Kendrick \& Carmichael (1973). Spore ontogeny was observed in slide culture (Riddell, 1950; McGinnis, 1974) on potato/dextrose (Difco), Sabouraud's (Difco) and glucose/peptone/yeast extract agars. Yeasts were characterized by our previous methods (Vishniac \& Hempfling, 1979).

Fungal physiology. Media used for plate counts were GPY medium [glucose $(0.5 \%, \mathrm{w} / \mathrm{v})$, peptone $(0.5 \%$, $\mathrm{w} / \mathrm{v})$, yeast extract $(0 \cdot 3 \%, \mathrm{w} / \mathrm{v})$ ] and GPYPi medium [GPY medium with potassium phosphate $(10 \mathrm{~mm}) \mathrm{pH}$ 6.86], both solidified with $1.8 \%(\mathrm{w} / \mathrm{v})$ agar. Growth responses in batch culture were determined as turbidity at $660 \mathrm{~nm}$ (using cuvettes of $1.0 \mathrm{~cm}$ path length and a Hitachi-Coleman Perkin-Elmer dual wavelength spectrophotometer, model 124) following growth on a synthetic medium containing Y-1 base $\left[\mathrm{NH}_{4} \mathrm{NO}_{3}(1 \cdot 25\right.$ $\mathrm{mM}), \mathrm{MgSO}_{4} .7 \mathrm{H}_{2} \mathrm{O}(2.0 \mathrm{~mm})$ and chelated trace metals solution (Vishniac \& Santer, 1957) $\left(10 \mathrm{ml} \mathrm{l}^{-1}\right)$ ] with phosphate buffer and glucose or other substrates added aseptically (as noted), made semi-solid by adding $0.1 \%(\mathrm{w} / \mathrm{v})$ agar or agarose and distributed in layers not more than $1 \mathrm{~cm}$ deep.

Substrate-limited chemostat cultures were initially grown in a medium consisting of glucose $(1.5 \mathrm{~mm})$, peptone $(0.1 \%, w / v)$ and yeast extract $(0.03 \%, w / v)$. Carbon and energy requirements reported were determined with synthetic medium [Y-1 base with potassium phosphate (10 mM) pH 6.86 and glucose $(5 \mathrm{~mm})]$. The $\mathrm{pH}$ of this medium remained constant at 6.5 during continuous culture.

Chemostat vessels were 1.21 Pyrex flasks ('Fleakers') modified by the addition of a doubly shielded over- 
flow drip, with independent air vent, in such a position as to provide a working volume of approximately 11. The dilution rate was controlled by the tubing diameter and the settings of a Harvard peristaltic pump. Filter-sterilized air was admitted at rates between 0.3 and $1.51 \mathrm{~h}^{-1}$ as required.

The chemostat (with all associated apparatus) was set up in a refrigerated room. For low-temperature experiments, the chemostat vessel was allowed to equilibrate with its surroundings, reaching, with aeration and insulation from the magnetic stirring motor, 1.0 to $2.5^{\circ} \mathrm{C}$ (varying only within $\pm 0.5{ }^{\circ} \mathrm{C}$ during any single run). Removing the stirring motor insulation and wrapping motor and vessel together in 'plastic bubble wrap' enabled us to maintain temperatures of 9.5 to $11^{\circ} \mathrm{C}$ (varying $\pm 0.5^{\circ} \mathrm{C}$ in any single run) for higher temperature growth.

The progress of cultures was determined daily as turbidity, as for batch cultures. The yield was measured as dry weight of $10 \mathrm{ml}$ samples; these were centrifuged for $10 \mathrm{~min}$ at $6000 \mathrm{~g}$ at $4{ }^{\circ} \mathrm{C}$, and the cells were washed once with $2 \mathrm{ml}$ cold distilled water, quantitatively transferred to tared, pre-dried aluminium weighing pans with $1.2 \mathrm{ml}$ double-distilled water, and dried to constant weight at $95^{\circ} \mathrm{C}$.

Glucose was determined in supernatant fractions of effluent samples and in medium reservoir samples by the glucose oxidase method ('Glucostat Special': Worthington Biochemical Corp., Freehold, N.J. 07728, U.S.A.).

\section{RESULTS AND DISCUSSION}

The location and description of sample sites and the water content, $\mathrm{pH}$ values, $\mathrm{C}, \mathrm{N}, \mathrm{K}^{+}$, $\mathrm{Na}^{+}, \mathrm{Ca}^{2+}, \mathrm{Mg}^{2+}$ and inorganic phosphate contents of the soil samples are given in Table 1 .

All enrichment and isolation procedures yielded microbial isolates from each sample subjected to them. None provided isolates of primary producers or of nitrogen-fixing organisms. Yeasts did not appear on plates strewn with ground rock particles, although bacterial colonies did, presumably because of the delicate balance between liberation and destruction of cells present in interstices.

\section{Taxa found}

Filamentous fungi were isolatable only within the year after soil samples were obtained. Of the seven soil samples $(201,202,302,303,304,306$ and 309) examined extensively during this time, 201, 303 and 306 yielded a total of 51 isolates of filamentous fungi. Sample 306 produced species of Alternaria, Aspergillus, Cladosporium, Geotrichum, Chrysosporium, Paecilomyces, Penicillium and Tritirachium as well as some Mycelia Sterilia; samples 201 and 303 produced only (the same) species of Cladosporium and Penicillium. No filamentous fungi were found which were not well-known from the temperate zone and either prominent or possible members of the airspora (with the obvious exception of Mycelia Sterilia). All grew optimally at or above the ambient laboratory temperature.

Yeasts were recovered at the time of the last subsampling on 9 April 1975, although samples 304, 306 and 309 no longer appeared to contain viable cells at this time. The only samples from which yeasts were not recovered $(203,301,307,308$ and 310$)$ were not examined until this time. Of the 106 yeast isolates characterized, 7 belonged to the Sporobolomycetaceae and 99 to the Cryptococcaceae.

All sporobolomycetaceous yeasts belonged to species not previously reported from the Antarctic: Tilletiopsis washingtonensis, Sporobolomyces holsaticus and Sporobolomyces roseus (two strains, separable by cellobiose assimilation, inter alia). These isolates, but no other yeasts, appeared after subsamples of 201, 303 and 306 were enriched with media containing $5 \% \mathrm{NaCl}$, but after no other treatment. It is possible that $5 \% \mathrm{NaCl}$ exerts a specific selective action. A similar species, $S p$. pararoseus, has been isolated from air (Pady, 1974). All isolates grew at $4{ }^{\circ} \mathrm{C}$ (poorly) and at $25^{\circ} \mathrm{C}$; the upper limit of temperature tolerance was not determined.

A single cryptococcaceous isolate from sample 306 was identified as Cryptococcus laurentii var. laurentii, previously reported from inshore waters along the Antarctic Peninsula by Fell (in Phaff \& Fell, 1971). This isolate grew optimally at $26^{\circ} \mathrm{C}$ (rather than 22 or $30^{\circ} \mathrm{C}$ ). The other 98 cryptococcaceous isolates could not be identified with any previously described species; they have been described as Cryptococcus vishniacii Vishniac \& Hempfling (1979), 
Table 1. Location and description of sample sites, and characterization of soil samples

\begin{tabular}{|c|c|c|c|c|c|c|c|c|c|c|c|c|}
\hline \multirow[b]{2}{*}{ No. } & \multirow[b]{2}{*}{ Location } & \multirow[b]{2}{*}{ Description } & \multicolumn{9}{|c|}{ Soil analysis (per g soil) } & \\
\hline & & & $\begin{array}{l}\text { Water } \\
(\mathrm{mg})\end{array}$ & $\mathrm{pH}$ & $\begin{array}{c}\mathrm{C} \\
(\mathrm{mmol})\end{array}$ & $\underset{(\mathrm{mmol})}{\mathrm{N}}$ & $\begin{array}{c}\mathrm{K}^{+} \\
(\mu \mathrm{mol})\end{array}$ & $\begin{array}{l}\mathrm{Na}^{+} \\
(\mu \mathrm{mol})\end{array}$ & $\begin{array}{c}\mathrm{Ca}^{2+} \\
(\mu \mathrm{mol})\end{array}$ & $\begin{array}{c}\mathbf{M g}^{2+} \\
(\mu \mathrm{mol})\end{array}$ & $\begin{array}{c}\mathrm{PO}_{4}{ }^{3-} \\
(\mathrm{nmol})\end{array}$ & \\
\hline 201 & $6600 \mathrm{ft}$; Loki ridge, east slope & $\begin{array}{l}\text { Dolerite slope, rocks with } \\
\text { loose soil, some sandstone }\end{array}$ & $9 \cdot 5$ & $6 \cdot 75$ & $3 \cdot 8$ & 一 & 0.06 & $17 \cdot 0$ & $0 \cdot 01$ & 0.01 & $6 \cdot 75$ & \\
\hline 202 & $6220 \mathrm{ft}$; north flank, Mt Baldr & $\begin{array}{l}\text { Coarse, weathered dolerite } \\
\text { gravel }\end{array}$ & $8 \cdot 9$ & $6 \cdot 65$ & $3 \cdot 4$ & $0 \cdot 4$ & 0.04 & $1 \cdot 0$ & 0 & 0.04 & $10 \cdot 7$ & \\
\hline 203 & $6520 \mathrm{ft}$; Baldr-Whiteface & Dolerite plain & $10 \cdot 7$ & $5 \cdot 22$ & $6 \cdot 0$ & $1 \cdot 5$ & $0 \cdot 15$ & $2 \cdot 2$ & 0.5 & $0 \cdot 32$ & 0 & 8 \\
\hline 301 & $4590 \mathrm{ft} ; 20^{\circ}$ from Center Cliff & Sand, fine & $5 \cdot 9$ & $6 \cdot 4$ & $4 \cdot 6$ & $2 \cdot 7$ & $0 \cdot 10$ & $22 \cdot 4$ & $7 \cdot 15$ & $6 \cdot 76$ & 0 & בֶ \\
\hline 302 & $\begin{array}{l}4870 \mathrm{ft} \text {; Center Cliff, near } \\
\text { middle of east slope }\end{array}$ & Dolerite terrace & $6 \cdot 0$ & $6 \cdot 25$ & $10 \cdot 0$ & $1 \cdot 1$ & $0 \cdot 10$ & $2 \cdot 7$ & 0.91 & $2 \cdot 73$ & 0 & 2 \\
\hline 303 & $4700 \mathrm{ft} ;$ foot of glacier & Dolerite moraine & $7 \cdot 5$ & $6 \cdot 85$ & $17 \cdot 8$ & 一 & $0 \cdot 10$ & $15 \cdot 1$ & $0 \cdot 16$ & $1 \cdot 41$ & $7 \cdot 16$ & s. \\
\hline 304 & $\begin{array}{l}4660 \mathrm{ft} \text {; slope of Baldr's } \\
\text { Bathtub }\end{array}$ & Sandstone, sand & $18 \cdot 1$ & $5 \cdot 32$ & $5 \cdot 4$ & $4 \cdot 9$ & $1 \cdot 14$ & $32 \cdot 3$ & 209 & $15 \cdot 9$ & $8 \cdot 56$ & $\frac{1}{8}$ \\
\hline 305 & $\begin{array}{l}4610 \mathrm{ft} ; 140^{\circ} \text { from } \mathrm{Mt} \text { Baldr } \\
\text { at foot of 'ramp' }\end{array}$ & Mixed dolerite and sand & $12 \cdot 1$ & $5 \cdot 45$ & $6 \cdot 0$ & 37 & 0.45 & 219 & 71 & $31 \cdot 2$ & 0 & 5 \\
\hline 306 & $\begin{array}{l}4750 \mathrm{ft} \text {; on escarpment in } \mathrm{NW} \\
\text { part of valley }\end{array}$ & Sandstone, sand & $3 \cdot 6$ & $5 \cdot 85$ & $5 \cdot 0$ & $0 \cdot 6$ & 0.92 & $1 \cdot 8$ & $0 \cdot 4$ & 0.64 & $17 \cdot 9$ & \\
\hline 307 & $\begin{array}{l}4680 \mathrm{ft} ; \text { floor of Baldr's } \\
\text { Bathtub }\end{array}$ & Mixed coarse sand & $8 \cdot 3$ & $6 \cdot 05$ & $11 \cdot 0$ & $1 \cdot 6$ & $0 \cdot 12$ & $8 \cdot 2$ & $10 \cdot 0$ & $4 \cdot 55$ & $14 \cdot 3$ & \\
\hline 308 & $\begin{array}{l}4080 \mathrm{ft} \text {; south slope, Wright } \\
\text { Valley, south of Center Cliff }\end{array}$ & Sandstone, fine sand & $4 \cdot 9$ & $5 \cdot 60$ & $0 \cdot 10$ & $9 \cdot 4$ & $5 \cdot 1$ & $9 \cdot 4$ & $5 \cdot 1$ & $2 \cdot 42$ & 0 & \\
\hline 309 & $2840 \mathrm{ft}$; Labyrinth, south of & Mixed sand, basalt columns & & & & (No sc & analysis & ample col & ected) & & & \\
\hline 310 & $\begin{array}{l}360 \mathrm{ft} ; 20 \mathrm{~m} \text { from edge of NE } \\
\text { part of Don Juan Pond }\end{array}$ & $\begin{array}{l}\text { Mixed sand (salt-caked), } \\
\text { including granite }\end{array}$ & $16 \cdot 3$ & $6 \cdot 40$ & $7 \cdot 5$ & $0 \cdot 4$ & $0 \cdot 4$ & 2848 & 399 & $1 \cdot 29$ & $17 \cdot 2$ & \\
\hline
\end{tabular}




\section{Table 2. Distribution of groups by soil sample}

The presence of a group member in a soil sample is indicated by + ; the numbers in parentheses designate the biotypes present.

\begin{tabular}{|c|c|c|c|c|c|c|c|}
\hline \multirow{2}{*}{$\begin{array}{c}\text { Sample } \\
\text { no. }\end{array}$} & \multirow{2}{*}{$\begin{array}{l}\text { Cr. laurentii } \\
\text { var. laurentii }\end{array}$} & \multicolumn{6}{|c|}{ Cr. vishniacii group } \\
\hline & & vishniacii & wolfii & vladimirii & wrightensis & baldrensis & rhamnovorans \\
\hline 202 & & & & $+(4)$ & & $+(11,12,13)$ & \\
\hline 302 & & & & $+(4,5)$ & & $+(10,12,14)$ & $+(16)$ \\
\hline 303 & & $+(7,8)$ & $+(1,2)$ & $+(3,4,6)$ & $+(9)$ & $+(13,15)$ & \\
\hline 304 & & $+(7)$ & & & & $+(12)$ & \\
\hline 306 & + & & & $+(6)$ & & $+(12)$ & \\
\hline 309 & & & & $+(4)$ & & & \\
\hline
\end{tabular}

a species comprising 16 biotypes forming a single cluster at the $93.5 \%$ similarity level. It is remarkable that these isolates appeared after autotrophic enrichments (Hydrogenomonas, Nitrosomonas), enrichments for methane-oxidizers, in subsamples held in light or dark for up to $46 \mathrm{~d}$ at 10 to $12{ }^{\circ} \mathrm{C}$ before isolation, on media lacking nitrogen sources, as well as on soil particles (washed or unwashed) sprinkled on heterotrophic medium and in percolated heterotrophic medium. Cryptococcus vishniacii appeared after every treatment which did not involve grinding soil particles or the presence of $5 \% \mathrm{NaCl}$, at temperatures ranging from 2 to $15^{\circ} \mathrm{C}$. These organisms either starve gracefully or are efficient scavengers.

\section{Distribution of taxa by sample site}

The filamentous fungi were distributed as would be expected for airspora surviving for periods depending upon the degree of environmental stress at each sample site; no taxa were found at less species-diverse sites which did not occur at the favoured site (306). Of the yeasts, only the cryptococcaceous isolates were considered to have been adequately recovered from soil samples. For the purposes of distribution analysis, each biotype of $\mathrm{Cr}$. vishniacii could be assumed to represent a distinct population. We chose instead to analyse the distribution of groups of biotypes (biasing the result in favour of that expected for allochthonous organisms) because experimental conditions (discussed below) consistently affected some biotype characters (cardinal temperature, assimilation of tricarboxylic acid cycle-related substrates, and possibly ammonium toxicity).

Biotypes were grouped as follows: group 'wolfii', biotypes 1 and 2 (characterized by weak assimilation of rhamnose only in addition to the substrates assimilated by the species in common); group 'vladimirii', biotypes 3 to 6 (assimilation pattern as for wolfii, plus sucrose and raffinose); group 'vishniacii', biotypes 7 and 8 (assimilation pattern as for vladimirii, plus L-arabinose); group 'wrightensis', biotype 9 (assimilation of cellobiose and salicin, sucrose and raffinose, and methyl- $\alpha$-D-glucoside in addition to the substrates assimilated by the species in common); group 'baldrensis', biotypes 10 to 15 (assimilation pattern as for wrightensis, plus L-arabinose); group 'rhamnovorans', biotype 16 (assimilation pattern as for baldrensis plus L-rhamnose). This distribution of these groups of $\mathrm{Cr}$. vishniacii and Cr. laurentii is given in Table 2 . This distribution is more nearly random (site 303 contained the greatest number of groups, but not all groups, and group vladimirii, the most common, was not found at all sites) than that of the filamentous fungi. Since Cr. vishniacii is (as postulated) a unique taxon, distributed as predicted for a Dry Valley indigene, we proceeded to examine its congruence with other model attributes.

\section{Effects of temperature}

Cryptococcus vishniacii is capable of growth from at least $-3{ }^{\circ} \mathrm{C}$ to all but the most extreme high temperatures (no isolate grew at $26^{\circ} \mathrm{C}$ ) occurring in the Dry Valleys, the 
Table 3. Growth responses to near-maximal temperatures

Turbidity was determined after $4 \mathrm{~d}$ incubation at the indicated temperature in $\mathrm{Y}-1$ semi-solid medium, $\mathrm{pH} 6 \cdot 0$, with $0.25 \%(\mathrm{w} / \mathrm{v})$ glucose. Inocula (cell suspensions from $4{ }^{\circ} \mathrm{C}$ stock cultures) were adjusted to give an initial $A_{660}$ of 0.05 to 0.065 . Lower $A^{20} / A^{23}$ ratios indicate greater temperature tolerance.

\begin{tabular}{|c|c|c|c|c|}
\hline \multirow[b]{2}{*}{ Biotype } & \multirow[b]{2}{*}{ Isolate } & \multicolumn{2}{|c|}{$A_{660}$} & \multirow{2}{*}{$\begin{array}{c}\text { Ratio } \\
A^{20} / A^{23}\end{array}$} \\
\hline & & $20^{\circ} \mathrm{C}$ & $23^{\circ} \mathrm{C}$ & \\
\hline 1 & $303 Y 216$ & $1 \cdot 1$ & $0 \cdot 4$ & $2 \cdot 75$ \\
\hline 4 & $309 Y 215$ & $1 \cdot 1$ & 0.4 & $2 \cdot 75$ \\
\hline 9 & $303 Y 206$ & $1 \cdot 6$ & $1 \cdot 1$ & 1.45 \\
\hline 10 & $302 Y 265$ & $1 \cdot 3$ & 0.9 & 1.44 \\
\hline 11 & $202 Y 349$ & $1 \cdot 1$ & $0 \cdot 8$ & $1 \cdot 38$ \\
\hline 14 & $302 Y 259$ & $1 \cdot 4$ & 0.9 & $1 \cdot 56$ \\
\hline 16 & $302 Y 310$ & $1 \cdot 6$ & $1 \cdot 1$ & $1 \cdot 45$ \\
\hline
\end{tabular}

Table 4. Proportions of temperature-variant cells in populations of Cr. vishniacii 304Y268

Quintuplicate plates (GPYPi) were spread (over ice) and counted after incubation for 28 to $37 \mathrm{~d}$ at $4{ }^{\circ} \mathrm{C}$ or 13 to $14 \mathrm{~d}$ at $10^{\circ} \mathrm{C}$ or $13 \mathrm{~d}$ at $20^{\circ} \mathrm{C}$. Counts shown are of populations grown under a variety of conditions which might influence the numbers of variants appearing. No attempt was made to maximize numbers of colony-forming units.

\begin{tabular}{|c|c|c|c|c|c|c|}
\hline \multirow{2}{*}{$\begin{array}{l}\text { Popu- } \\
\text { lation }\end{array}$} & \multicolumn{3}{|c|}{ No. of cells $\mathrm{ml}^{-1}$ forming colonies at: } & \multirow{2}{*}{$\begin{array}{l}\text { Temp. of } \\
\text { ' } 20^{\circ} \mathrm{C} \text { ' } \\
\text { incubator } \\
\left({ }^{\circ} \mathrm{C}\right)\end{array}$} & \multicolumn{2}{|c|}{ Ratio of counts } \\
\hline & $4{ }^{\circ} \mathrm{C}$ & $10^{\circ} \mathrm{C}$ & ' $20^{\circ} \mathrm{C}$ ' & & $10^{\circ} \mathrm{C} / 4^{\circ} \mathrm{C}$ & $' 20^{\circ} \mathrm{C} ' / 10^{\circ} \mathrm{C}$ \\
\hline 1 & $3 \cdot 74 \times 10^{7}$ & $3 \cdot 75 \times 10^{7}$ & $1 \cdot 16 \times 10^{5}$ & $21(9 d)-20$ & $1 \cdot 00$ & $3 \cdot 1 \times 10^{-3}$ \\
\hline 2 & $3.57 \times 10^{7}$ & $5.35 \times 10^{7}$ & $4.46 \times 10^{6}$ & 20 & $1 \cdot 50$ & $8 \cdot 3 \times 10^{-2}$ \\
\hline 3 & 一 & $2.63 \times 10^{7}$ & $1 \cdot 10 \times 10^{6}$ & 20 & $\longrightarrow$ & $4.2 \times 10^{-2}$ \\
\hline 4 & $6.72 \times 10^{7}$ & $7 \cdot 03 \times 10^{7}$ & 一 & - & 1.05 & 一 \\
\hline 5 & $1.07 \times 10^{8}$ & $1.07 \times 10^{8}$ & $1 \cdot 18 \times 10^{7}$ & $19 \cdot 5-20$ & $1 \cdot 00$ & $1 \cdot 1 \times 10^{-1}$ \\
\hline
\end{tabular}

uppermost limit varying with biotype (Vishniac \& Hempfling, 1979). Some biotypes would be psychrophilic (no growth above $20^{\circ} \mathrm{C}$ ) and others psychrotrophic (range extending into that of mesophiles, 20 to $40^{\circ} \mathrm{C}$ ) by definitions in common use (Morita, 1975). The stenothermic responses of some marine bacteria (Morita, 1975) would hardly be adaptive in more variable terrestrial systems. The bacteria isolated from more fertile Antarctic soils have broad temperature ranges, growing as 'low mesophiles' from 5 to $25^{\circ} \mathrm{C}$ (Cameron, 1971). The strict application of an arbitrary limit for psychrophiles seems unfortunate since it would exclude microbes with temperature limits a few degrees higher which are unable to compete with mesophiles (i.e. are not ecological psychrotrophs) at 20 to $25^{\circ} \mathrm{C}$. More precise assessment of the growth responses of $\mathrm{Cr}$. vishniacii isolates to temperature (i.e. by turbidity rather than the opacity of streaks on agar as in screening tests) gave results at variance with our initial observations (Vishniac \& Hempfling, 1979): cloned populations of even the most temperature-tolerant $\mathrm{Cr}$. vishniacii isolates, grown and maintained at $4{ }^{\circ} \mathrm{C}$ (routine for stock cultures), grew poorly at 20 and $23{ }^{\circ} \mathrm{C}$ (Table 3 ; see Table 6 for examples of the higher turbidity of temperature-tolerant isolates grown at $10^{\circ} \mathrm{C}$ than at $20^{\circ} \mathrm{C}$ ). Cryptococcus vishniacii should be regarded as psychrophilic.

Discrepancies in the temperature responses of yeasts have been reported previously by Fell (1974, discrepancy between laboratory responses and habitat temperature) and by Buhagiar \& Barnett (1971, discrepancy between temperatures required for isolation and subsequent behaviour of isolates) among others. Such inconsistencies, and the effects of exposure to relatively high temperatures (whether in the Dry Valleys or during transport between Antarctica and New York), are pertinent to the discussion of psychrophily as an indicator of fitness to the Dry Valley habitat.

It was noted during screening experiments that death need not follow promptly upon 
Table 5. Proportions of temperature-variant cells in representative cellobiose-utilizing isolates

Triplicate or quintuplicate plates containing $0.5 \mathrm{ml}$ samples of distilled water suspensions mixed with GPY agar at the lowest practical temperature were counted after 7 and $14 \mathrm{~d}$. No attempt was made to maximize numbers of colony-forming units.

\begin{tabular}{|c|c|c|c|}
\hline \multirow[b]{2}{*}{ Isolate } & \multicolumn{2}{|c|}{$\begin{array}{c}\text { No. of cells } \mathrm{ml}^{-1} \text { forming colonie } \\
\text { at: }\end{array}$} & \multirow{2}{*}{$\begin{array}{l}\text { Ratio of counts } \\
21-22^{\circ} \mathrm{C} / 10^{\circ} \mathrm{C}\end{array}$} \\
\hline & $10^{\circ} \mathrm{C}$ & $21-22^{\circ} \mathrm{C}$ & \\
\hline $\begin{array}{l}302 Y 265 \text { (biotype } 10 \text { ) } \\
\text { 202Y252 (biotype } 12 \text { ) } \\
\text { 202Y252 (biotype } 12 \text { ) }\end{array}$ & $\begin{array}{l}3 \cdot 8 \times 10^{7} \\
1 \cdot 3 \times 10^{7} \\
2 \cdot 25 \times 10^{7}\end{array}$ & $\begin{array}{l}7 \cdot 8 \times 10^{6} \\
3 \cdot 6 \times 10^{4} \\
7 \cdot 7 \times 10^{3}\end{array}$ & $\begin{array}{l}2 \times 10^{-1} \\
3 \times 10^{-3} \\
3 \times 10^{-3}\end{array}$ \\
\hline $\begin{array}{l}\text { Y252-10* } \\
\text { Y252-RT* }\end{array}$ & $\begin{array}{l}6 \cdot 1 \times 10^{7} \\
6.5 \times 10^{6}\end{array}$ & $\begin{array}{l}9.0 \times 10^{4} \\
2.6 \times 10^{6}\end{array}$ & $\begin{array}{l}1.5 \times 10^{-3} \\
4 \times 10^{-1}\end{array}$ \\
\hline
\end{tabular}

exposure to temperatures which did not permit growth, and that thermal death points were not uniform for all cells. Plates re-incubated at $10{ }^{\circ} \mathrm{C}$ following exposure to 26 to $27^{\circ} \mathrm{C}$ or 31 to $32{ }^{\circ} \mathrm{C}$ for $5 \mathrm{~d}$ contained some surviving colony-forming units. For example, some cells of isolates 202Y321, 202Y348, 202Y349, 303Y368 and 202Y375 survived 26 to $27^{\circ} \mathrm{C}$; some cells of 202Y336*, 202Y347*, 303Y354, 303Y362, 303Y364 and 303Y365 survived 31 to $32{ }^{\circ} \mathrm{C}$ ( $*$ though failing to survive 26 to $27^{\circ} \mathrm{C}$ ); whereas $303 \mathrm{Y} 338$ and $202 \mathrm{Y} 346$ survived neither temperature in one such experiment.

Populations of $\mathrm{Cr}$. vishniacii isolates were, moreover, not homogeneous in their response to temperatures which did allow growth. Variants appeared as 'spots', clones of cells, on the thin layer (averaging less than one cell thick) of cells laid down on multiply inoculated plates growing at or near maximum temperatures. This heterogeneity of response persisted in the type isolate, 304Y268, after repeated cloning and maintenance at $4{ }^{\circ} \mathrm{C}($ Table 4). Populations which failed to grow upon ordinary subculture at $20^{\circ} \mathrm{C}$, proved (when diluted for plate counts) to contain some colony-forming units tolerant to $20^{\circ} \mathrm{C}$ (the ratio of colony-forming units at $20^{\circ} \mathrm{C}$ to those at $10^{\circ} \mathrm{C}$ varied from $1 \cdot 1 \times 10^{-1}$ to $3 \cdot 1 \times 10^{-3}$, see Table 4). This ratio did not appear to be correlated with the conditions under which the populations had been produced [batch (exponential phase) versus continuous culture; relatively low $(\mu=0 \cdot 007)$ versus high $(\mu=0.0235)$ growth rates; low $\left(A_{660}=1 \cdot 0\right)$ versus high $\left(A_{660}=4.45\right.$, with clumping) densities; natural (GPYPi) versus substrate-limited synthetic (Y-1) media; low $\left(1.5\right.$ or $\left.2^{\circ} \mathrm{C}\right)$ versus near-optimal $\left(10\right.$ or $\left.11^{\circ} \mathrm{C}\right)$ temperatures], but rather with minor variations in the temperature of the ' $20^{\circ} \mathrm{C}$ ' incubator. Counts with plates incubated at $10{ }^{\circ} \mathrm{C}$ were never significantly lower than those with plates incubated at $4{ }^{\circ} \mathrm{C}$ (as illustrated in Table 4), although they were sometimes higher, presumably because of technical difficulties consequent upon the long periods of incubation required at the latter temperature.

Hagler \& Lewis (1974) found that the presence of utilizable sugars markedly increased thermal injury to yeasts with $T_{\max }$ ranging from 20 to $45^{\circ} \mathrm{C}$. Substrate-accelerated death in prokaryotes has been known for some years (see Dawes, 1976). It is therefore not surprising that temperature screening on nutrient-rich medium (GPY agar) gave lower maxima ('spots' or no growth at 21 to $22^{\circ} \mathrm{C}$ ) for some isolates (biotypes $9,11,12$ and 13) of the cellobioseassimilating groups than did screening on more nutrient-limited medium (cornmeal agar). Other isolates (biotypes 10,14 and 16) of the same groups showed no difference in $T_{\max }$, although growth was less dense on cornmeal agar. Plate counts of isolates representing each response revealed that the majority of cells in either case were incapable of growth at 21 to $22{ }^{\circ} \mathrm{C}$ (Table 5), suggesting that the initial observations of greater temperature tolerance for isolates resembling biotype 10 resulted from the higher proportion $(20 \%)$ of temperaturevariant cells present compared with isolates represented by biotype $12(0 \cdot 3 \%$ or less). 
Table 6. Effect of temperature stress on the ability of uncloned populations subcultured at critical temperatures to utilize TCA-cycle substrates

Large populations $\left(10^{9}\right.$ to $10^{10}$ cells) of each isolate were exposed to $20^{\circ} \mathrm{C}$ (series A) or 25 to $26^{\circ} \mathrm{C}$ (series B) for 2 to 4 weeks. Then, for each series, equivalent numbers of cells (of undetermined viability) were subcultured at the temperatures indicated in semi-solid Y-1 media containing sodium succinate $(0.5 \%, \mathrm{w} / \mathrm{v})$ or sodium citrate $(0.5 \%, \mathrm{w} / \mathrm{v})$ or glucose $(0 \cdot 1 \%, \mathrm{w} / \mathrm{v})$. The results show the $A_{660}$ values after $10 \mathrm{~d}$ incubation (series A includes, in parentheses, equivalent results for subculture at $10^{\circ} \mathrm{C}$ ). For uninoculated medium, $A_{660}$ was $0 \cdot 1$. Biotypes 9 and 10 were included in both series to illustrate the relative behaviour of more temperature-tolerant biotypes at $20^{\circ} \mathrm{C}$. Unexposed populations of other biotypes included in series A reached $A_{660}$ values of 2.4 to 2.8 on succinate medium and $2 \cdot 1$ on citrate medium after $10 \mathrm{~d}$ at $10^{\circ} \mathrm{C}$ in equivalent experiments. The notation ' $\mathrm{na}$ ' is used when the biotype in question is defined in part by non-assimilation of the substrate.

\begin{tabular}{|c|c|c|c|}
\hline \multirow[b]{2}{*}{ Isolate/Biotype } & \multicolumn{3}{|c|}{ Substrate } \\
\hline & Succinate & Citrate & Glucose \\
\hline \multicolumn{4}{|c|}{ Series $\mathrm{A}$ : exposed to $20^{\circ} \mathrm{C}$, subcultured at $20^{\circ} \mathrm{C}$ (and $10^{\circ} \mathrm{C}$ ) } \\
\hline $303 Y 216 / 1$ & $0.7(1.9)$ & na & $2 \cdot 6(3 \cdot 15)$ \\
\hline $303 Y 365 / 2$ & 0.5 & na & $2 \cdot 4$ \\
\hline $303 Y 200 / 3$ & $0 \cdot 7(2 \cdot 1)$ & na & $2 \cdot 4(3 \cdot 15)$ \\
\hline $309 Y 215 / 4$ & $0.9(1.75)$ & na & $2 \cdot 4(3 \cdot 4)$ \\
\hline $304 Y 268 / 7$ & $0 \cdot 1(1 \cdot 5)$ & $0 \cdot 2(1 \cdot 5)$ & $1 \cdot 75(3 \cdot 0)$ \\
\hline $303 Y 338 / 8$ & 0.85 & $0 \cdot 2$ & $2 \cdot 3$ \\
\hline $303 Y 206 / 9$ & $1.7(1.95)$ & $1.4(1 \cdot 8)$ & $2.9(3.45)$ \\
\hline $302 Y 265 / 10$ & $1 \cdot 7(2 \cdot 1)$ & $1 \cdot 7(2 \cdot 0)$ & $2.9(3.45)$ \\
\hline
\end{tabular}

Series B: exposed to 25 to $26^{\circ} \mathrm{C}$; subcultured at 23 to $24{ }^{\circ} \mathrm{C}$

$\begin{array}{llll}303 Y 206 / 9 & 0 \cdot 4 & 0 \cdot 3 & 1 \cdot 1 \\ 302 Y 265 / 10 & 0 \cdot 4 & 0 \cdot 4 & 1 \cdot 2 \\ 306 Y 250 / 12 & \text { na } & 0 \cdot 3 & 1 \cdot 9 \\ 202 Y 375 / 13 & \text { na } & 0 \cdot 25 & 1 \cdot 9 \\ 302 Y 259 / 14 & \text { na } & 0 \cdot 3 & 1 \cdot 8 \\ 302 Y 310 / 16 & 0 \cdot 2 & 0 \cdot 25 & 1 \cdot 6\end{array}$

Selected colonies of $202 \mathrm{Y} 252$ (biotype 12) from both the $10^{\circ} \mathrm{C}$ and the 21 to $22^{\circ} \mathrm{C}$ plates, recloned at $10^{\circ} \mathrm{C}$ (manipulated on ice) and 21 to $22^{\circ} \mathrm{C}$ respectively, were clearly distinguishable by failure to grow in $7 \mathrm{~d}$ on GPY agar at room temperature and at $4{ }^{\circ} \mathrm{C}$ respectively, demonstrating a shift in range rather than a simple extension of $T_{\max }$. The clone Y252-RT (Room Temperature, 21 to $22{ }^{\circ} \mathrm{C}$, selection) also grew less well at $10^{\circ} \mathrm{C}$ than did the clone Y252-10 $\left(10^{\circ} \mathrm{C}\right.$ selection); for example, Y252-RT grew to $A_{660} 1.1$ in $7 \mathrm{~d}$ on semi-solid Y-1 medium with $0 \cdot 1 \%(\mathrm{w} / \mathrm{v})$ glucose, while an equivalent inoculum of Y252-10 reached $A_{660} 1 \cdot 5$. Yet both clones, tested as soon as practical after selection, were heterogeneous (Table 5); Y252-10 contained temperature variants at a slightly lower level $(0 \cdot 15 \%)$ than the parent population, while Y252-RT contained a sufficiently high level (40\%) of variants to respond to GPY as biotype $10 \mathrm{had}$.

Re-investigation of the substrate assimilation pattern of both parental and derived clones of Y252 revealed a single anomaly: Y252-RT failed to assimilate citrate at either 10 or $20^{\circ} \mathrm{C}$. Evison \& Rose (1965) have reported diminished activity of some tricarboxylic acid (TCA) cycle enzymes in a psychrophilic Candida (A3E-2) after transfer to temperatures above the maximum for growth.

Heterogeneity in temperature response patterns, with higher $T_{\max }$ accompanied by impairment of ability to utilize the TCA-cycle related substrates citrate and succinate (but no other change in substrate assimilation patterns), was observed in representative isolates of each biotype of $\mathrm{Cr}$. vishniacii. (Biotypes 6 and 15, which assimilated neither substrate, were excluded from this series of experiments.) Large populations $\left(10^{9}\right.$ to $10^{10}$ cells $)$ of isolates of groups wolfii, vladimirii and vishniacii were exposed to the critical temperature of $20^{\circ} \mathrm{C}$, 
and of groups wrightensis, baldrensis and rhamnovorans to the critical temperature of 25 to $26^{\circ} \mathrm{C}$ for periods of 2 weeks to 1 month. The growth response of uncloned subcultures to citrate, succinate and glucose at near $T_{\max }$ (compared in one series to growth at $10{ }^{\circ} \mathrm{C}$ ) is shown in Table 6, together with examples of absence of stress at $20^{\circ} \mathrm{C}$ for representative cellobiose-utilizing biotypes ( 9 and 10 ).

Confirmation of temperature response and TCA-cycle substrate utilization change was obtained for selected clones of biotypes $2,5,7$ and 8 only by multipoint testing on citrate and succinate agars $\left(10^{\circ} \mathrm{C}\right)$ and GPY agar $\left(10\right.$ and $\left.20^{\circ} \mathrm{C}\right)$. These clones proved difficult to maintain with available temperature-control equipment. Selected clones of biotypes 1 (2 clones), 4 (1), 9 (2), 10 (2), 11 (3), 12 (2), 13 (3), 14 (2) and 16(3) were recharacterized for biotypical substrate assimilation patterns and for nitrate utilization. The failure of these clones to assimilate citrate and succinate (only, of substrates assimilated by parental isolates) at any test temperature $\left(10,20\right.$ and $\left.23{ }^{\circ} \mathrm{C}\right)$ indicated their derivation from non-assimilating cells.

Reversion to citrate or succinate utilization was possible since 'spots' appeared irregularly during these experiments, at any temperature which allowed growth on other substrates. Possibly reversionary changes in the biotypical character of succinate-negative biotypes 12 (306Y250) and 14 (302Y259) were also manifest as succinate-positive 'spots' at each test temperature. The stock cultures of these isolates had been maintained at $4{ }^{\circ} \mathrm{C}$ for nearly a year and a half at the time of these experiments.

The possibility that ammonium sensitivity, a character distinguishing some $\mathrm{Cr}$. vishniacii biotypes, was the result of heat stress is suggested by the finding of Struhl \& Magasanik (1976) that ammonium sensitivity follows damage to the TCA-cycle enzyme, 2-oxoglutarate dehydrogenase.

Exposure to $30{ }^{\circ} \mathrm{C}$ for $7 \mathrm{~d}$ did not enrich temperature variants among the survivors $\left(3 \times 10^{-6}\right.$ of cells present initially) nor did lyophilized cultures held at room temperature show any subsequent alterations in temperature response or substrate assimilation pattern. Exposure to temperatures sufficiently above $T_{\max }$ or under non-growing conditions does not change biotype characteristics.

Exposure to critical temperatures near $T_{\max }$ both in situ and during transport may be presumed to have changed the proportions of temperature variants in soil samples, resulting in the isolation as distinct biotypes of cells derived from identical parent populations. The presence, even in populations grown at $4{ }^{\circ} \mathrm{C}$, of cells able to grow with metabolic impairment at elevated temperatures may be an adaptation to environmental variability. If competing yeasts were present, such an adaptation would be useless; mesophilic yeasts, such as $\mathrm{Cr}$. albidus, rapidly outgrow $\mathrm{Cr}$. vishniacii at $20^{\circ} \mathrm{C}$ or higher temperatures. Competing yeasts are absent, but since neither population size nor variant frequency in the Dry Valleys is precisely known, the degree of usefulness of such an adaptation cannot be estimated.

\section{Carbon and energy budget}

A preliminary notion of the magnitude of the carbon and energy requirements of $\mathrm{Cr}$. vishniacii may be gleaned from the following data for the type isolate 304Y268. Our previous experience with $C r$. vishniacii isolates led us to believe that the response of growth rate to temperature would be linear between 4 and $10^{\circ} \mathrm{C}$. Minimum doubling times $\left(T_{\mathrm{d}}\right)$ observed in batch culture (shaken flasks of GPYPi medium) at 4 to $5{ }^{\circ} \mathrm{C}$ and $10.5{ }^{\circ} \mathrm{C}$ were $24 \mathrm{~h}$ and $10.5 \mathrm{~h}$, respectively, corresponding to specific growth rates of $0.0288 \mathrm{~h}^{-1}$ and $0.0657 \mathrm{~h}^{-1}$ $\left[\mu=\left(1 / T_{\mathrm{d} \text {, batch }}\right) \times 0 \cdot 69\right]$. The theoretical Arrhenius plot (slope -0.47$)$ derived from these two points was useful in extrapolating to lower temperatures. The time required for chemostat growth at $1.5^{\circ} \mathrm{C}$, assuming that about $20 \mathrm{~d}$ should elapse to ensure attainment of a steady state at $D=0.01 \mathrm{~h}^{-1}$, limited our exploration of this area. Washout of cells, coupled with an increase in glucose in the effluent, began as predicted at specific growth rates just 
Table 7. Yield and maintenance data during glucose-limited continuous culture at $10{ }^{\circ} \mathrm{C}$

\begin{tabular}{|c|c|c|c|c|c|}
\hline$\mu\left(\mathrm{h}^{-1}\right)$ & $\begin{array}{c}\text { Dry weight } \\
\left(\mu \mathrm{g} \mathrm{ml}^{-1}\right)\end{array}$ & $\begin{array}{l}\text { Glucose } \\
\text { in } \\
\text { reservoir } \\
(\mathrm{mM})\end{array}$ & $Y_{\mathrm{s}}$ & $\left(1 / Y_{\mathrm{S}}\right) \times 10^{3}$ & $1 / \mu$ \\
\hline $\begin{array}{l}0.0094 \\
0.0198\end{array}$ & $\begin{array}{l}352 \\
412 \cdot 5\end{array}$ & $\begin{array}{l}5 \\
5\end{array}$ & $\begin{array}{l}70 \cdot 4 \\
82.5\end{array}$ & 14 & \\
\hline $\begin{array}{l}0.0198 \\
0.023\end{array}$ & $\begin{array}{l}412 \cdot 5 \\
425\end{array}$ & $\begin{array}{l}5 \\
5\end{array}$ & $\begin{array}{l}82 \cdot 5 \\
85 \cdot 0\end{array}$ & $\begin{array}{l}12 \\
11 \cdot 8\end{array}$ & $\begin{array}{l}50 \cdot 5 \\
43 \cdot 3\end{array}$ \\
\hline $\begin{array}{l}0.023 \\
0.039\end{array}$ & 554.5 & 5 & 110.9 & 9.0 & $25 \cdot 6$ \\
\hline 0.039 & $570 \cdot 5$ & 5 & $114 \cdot 1$ & 8.8 & $25 \cdot 6$ \\
\hline 0.039 & $581 \cdot 5$ & 5 & $116 \cdot 3$ & 8.6 & $25 \cdot 6$ \\
\hline
\end{tabular}

The relationship between yield and $\mu$ (calculated using the mean of experimental data for $\mu=0.039 \mathrm{~h}^{-1}$ ) is given by the equation $\left(1 / Y_{\mathrm{S}}\right) \times 10^{3}=0.05(1 / \mu)+8 \cdot 5 ; r=0.897$.

over $0.01 \mathrm{~h}^{-1}$, confirming our assumption of the linearity of growth rate with temperature. The maximum specific growth rate at $1.5^{\circ} \mathrm{C}$ must then be near $0.02 \mathrm{~h}^{-1}$, as calculated. If the minimum specific growth rate is assumed to be $6 \%$ of $\mu_{\max }$ (see Pirt, 1975), it should be about $0.001 \mathrm{~h}^{-1}$ at $1.5^{\circ} \mathrm{C}\left(T_{\mathrm{d}} 26 \mathrm{~d}\right)$. The yield $\left[Y_{\mathrm{s}}=\mathrm{g}\right.$ dry wt cells/(mol glucose in reservoir mol glucose in effluent)] at $1.5^{\circ} \mathrm{C}, \mu=0.007 \mathrm{~h}^{-1}$, was 100 . The substrate required for a single division will vary with growth rate, since maintenance energy expenditure per generation increases as growth rate decreases.

As the temperature is raised, the time required for experimentation becomes conveniently shorter. We did not consider $15^{\circ} \mathrm{C}$ useful, not because this temperature is unusual in Dry Valley soils, but because Y252 clones appear to be unstable near this temperature (unpublished data). At around $10{ }^{\circ} \mathrm{C}$ we were able to calculate the maximum molar growth yield and maintenance energy requirements for 304Y268 from the double reciprocal plot of yield versus $\mu$ (data in Table 7). The intercept of this plot, the maximum molar growth yield (per $S_{R}-S_{E}$ ), is $117.6 \mathrm{~g}$ dry wt cells (mol glucose) ${ }^{-1}$. The maintenance requirement [the slope of this plot, given by the relation $\left.\left(1 / Y_{\mathrm{s}}\right) \times 10^{3}=0.05(1 / \mu)+8.5\right]$ is $20 \mathrm{mmol}$ glucose (g dry wt cells) ${ }^{-1} \mathrm{~h}^{-1}$. Since at $11^{\circ} \mathrm{C}$ lysis set in at $\mu=0.0061$, the minimum specific growth rate must be over $8.7 \%$ of the maximum rate calculated from the Arrhenius plot. The minimum $Y_{\mathrm{s}}$ at $10{ }^{\circ} \mathrm{C}$, with these assumptions, is $55.8 \mathrm{~g}$ (mol glucose) $)^{-1}$, that is the substrate required for reproduction is roughly doubled at the minimum growth rate. The yield figure for $1.5{ }^{\circ} \mathrm{C}$ growth so closely resembles the maximum yield at $10^{\circ} \mathrm{C}$ as to suggest that maintenance may be neglected at the lower temperature. The substrate requirement for doubling a population of 10 yeast cells in $1 \mathrm{~g}$ soil in situ must be of the order of 2 to 4 pmol $(0.3$ to $0.7 \mathrm{ng}$ ) glucose (at temperatures up to $10^{\circ} \mathrm{C}$ ).

In aqueous environments, growth rate is hyperbolically dependent upon substrate concentration, with the half-maximal rate occurring when the concentration equals $K_{\mathrm{s}}$ (the saturation constant). Scavenging ability, indicated by a low $K_{\mathrm{s}}$ value, may determine the outcome of microbial competition (see Jannasch, 1967; Matin \& Veldkamp, 1978). The concentration of glucose in the effluent from the chemostat vessel $\left(10^{\circ} \mathrm{C}\right)$ at $\mu=0.039 \mathrm{~h}^{-1}$ was $2 \cdot 3$ to $3 \cdot 1 \mu \mathrm{g} \mathrm{ml}^{-1}(12 \cdot 8$ to $17 \cdot 2 \mu \mathrm{M})$. This concentration is near the limit of detection and is subject to correction for substrate consumed during centrifugation of the chemostat sample. The maximum correction (allowing for no cooling and $15 \mathrm{~min}$ preparation) required by the uptake of 8 to $9 \mathrm{nmol} \mathrm{O}_{2} \mathrm{~min}^{-1}$ (mg dry wt) ${ }^{-1}$ (determined polarographically at $10{ }^{\circ} \mathrm{C}$ ) would be $13 \mu \mathrm{M}$. At $0.039 \mathrm{~h}^{-1}, \mu$ is near the half-maximal specific growth rate of batch culture - one may take $K_{\mathrm{s}}$ as equal to 13 to $<26 \mu \mathrm{M}$ or calculate $K_{\mathrm{S}}=\overline{\mathrm{S}}\left(\mu_{\max }-D\right) /$ $D$ to obtain 9 to $<18 \mu \mathrm{M}$. The role of the $K_{\mathrm{s}}$ value in a system which is neither aquatic nor homogeneous (i.e. in situ) is debatable, but this value is sufficiently low (see Pirt, 1975, for $K_{\mathrm{s}}$ values of bacteria and fungi) to suggest that $C r$. vishniacii may be a relatively efficient scavenger. 
The very low organic content of Dry Valley soils is not a deterrent to the growth of $C r$. vishniacii. The calculated substrate requirement would have to increase by several orders of magnitude before limitation could be detected by direct soil analysis. It has been reported (Horowitz et al., 1972) that, given additional water, soils of this area contain sufficient organic matter to permit increases in microbial populations. It is necessary to find a source of continuing input to this supply. While primary producers are also indigenous to this area (the endolithic cyanobacteria of Friedmann \& Ocampo, 1976), data on their productivity are not available, nor has the energy flow in such a community been studied. The order of magnitude of energy input from airspora can be surmised. Quantitative data are hard to find; Gregory (1966) cites a report of 137 fungal spores $\mathrm{m}^{-3}$ in an air mass of polar origin. Given the tendency of airspora to fall out (Gregory, 1973) and the isolation of non-adapted microbes from the Dry Valley area (Horowitz et al., 1972), we may assume prior deposition. If two spores of $20 \mathrm{pg}$ dry wt, containing $14 \%$ trehalose (a possibility suggested by data in Sussman \& Halvorson, 1966), were strategically deposited per hour, the trehalose content alone would (as glucose) be sufficient to support the production of 10 yeast cells at the minimum growth rate at $10^{\circ} \mathrm{C}$, while the deposition of 11 spores $\mathrm{h}^{-1}$ would allow the maximum rate of doubling at this temperature. It is reasonable to conclude that the airspora supplies a significant fraction of heterotrophic requirements in the Dry Valleys.

\section{Cryptococcus vishniacii as an indigene}

Since $C r$. vishniacii is known only from the Dry Valleys (unique taxon), is distributed more randomly than allochthones and has temperature and carbon (and other nutrient) and energy requirements permitting reproduction in the environment of the Dry Valleys, the most economical conclusion is that these yeasts are indigenes. Is this species congruent with the model indigene in other respects? We have not established its microhabitat. The extreme aridity of the Dry Valleys has been considered the most limiting factor for life (Howowitz et al., 1972) but $\mathrm{Cr}$. vishniacii is not markedly xerophilic, since it will grow neither in the presence of $1.96 \mathrm{M}(18 \%, \mathrm{w} / \mathrm{v})$ glycerol nor $1.55 \mathrm{M}(9 \%, \mathrm{w} / \mathrm{v}) \mathrm{NaCl}$ (Vishniac \& Hempfling, 1979). It is desiccation-resistant under the conditions of lyophilization, conditions which resemble those of its environment. Furthermore, the water activity of 0.45 or less which has been said to characterize the Dry Valleys (Horowitz et al., 1972), while demonstrably correlated with overall microbial diversity and abundance, has little relevance to the life of an individual microbe in a microhabitat in soils there. The spatial and temporal distribution of water is heterogeneous; liquid water does occur.

What specific adaptations constitute Cr. vishniacii's advantage over other yeasts? Previous investigations of the Antarctic continent (see Cameron, 1971, 1974) and of the surrounding waters (Fell, 1974) have yielded a variety of yeast species of low abundance. The only common character which separates terrestrial species from $\mathrm{Cr}$. vishniacii (see accounts of isolation and physiology, and Barnett \& Pankhurst, 1974) is occurrence in soils of greater organic content than those of the Dry Valleys. Di Menna (1966) found yeasts typically associated with obvious plant material (mosses or algae); Goto et al. (1969) associated them with penguin dung. Data on carbon-limited growth are not available, even for the most studied yeasts, Leucosporidium spp. of soil and water.

Psychrophily in Antarctic species has been well-investigated (see Goto et al., 1969; Arthur \& Watson, 1976; Watson et al., 1976). Leucosporidium scottii and Torulopsis psychrophila are as or more narrowly psychrophilic than Cr. vishniacii. The Leucosporidium spp. studied by Watson et al. (1976) appear to grow slightly faster than Cr. vishniacii at mean environmental summer temperatures ( $\mu$ and Arrhenius characteristic recalculated from the data of Watson et al., 1976). Torulopsis psychrophila does not utilize nitrate, but the Leucosporidium spp. uniformly do. Some require growth factors, but $L$. scottii does not. Leucosporidium (Candida) nivale, L. gelidum and $L$. frigidum are xerophilic, growing in the presence of $15 \% \mathrm{NaCl}$ (di Menna, 1966), but most Antarctic yeasts resemble Cr. vishniacii 
in lacking high $\mathrm{NaCl}$ tolerance (Goto et al., 1969). Leucosporidium scottii was found most commonly by di Menna (1966) and was among the most numerous isolates of Goto et al. (1969); there is no documented reason for its non-occurrence in the most inhospitable Dry Valley soils.

Finding a theoretically complete ecology in the Dry Valleys, possible minimal communities of indigenous primary producers (endolithic cyanobacteria) and heterotrophic consumers (Cr. vishniacii), has further implications. The Antarctic ecosystem has attracted interest not only for its own sake but because this environment is the most similar to that of Mars that Earth can muster. The usefulness of the Dry Valleys as a Martian model has waned with the increased knowledge of the Martian environment produced by the Viking programme. The results of the life-detection experiments of that programme have been shown to require no biological explanations. But the Dry Valley ecosystem still has heuristic value. Since microbial communities do exist in our planet's coldest desert, the known frontiers of life are farther out than had been thought. Since Dr W. V. Vishniac's faith in microbial adaptability led him to look more thoroughly and successfully in the Dry Valleys for indigenous microbes, a number of apparent truisms are once again worth repeating. What you find depends on how well you look. There can be no standard methods for new organisms. The Dry Valley yeasts were not isolated by standard methods for enumerating and isolating yeasts. A fresh approach to extraterrestrial microbiology might produce equally fresh answers.

This study was supported by a grant (NGR-33-019-002) from the Office of Space Sciences, National Aeronautics and Space Administration, Washington, D.C. The senior author is grateful for support as Florence B. Seibert Fellow of the American Association of University Women during part of this study. We are happy to thank T. Kurtz, C. Rice and I. Uydess for isolations and S. Daloia, T. Kurtz and C. Nersinger for other assistance. We are further grateful to C. Rice for soil analyses.

\section{REFERENCES}

Arthur, H. \& WATson, K. (1976). Thermal adaptation in yeast: growth temperatures, membrane, lipid, and cytochrome composition of psychrophilic, mesophilic, and thermophilic yeasts. Journal of Bacteriology 128, 56-68.

Barnett, J. A. \& Pankhurst, H. J. (1974). A New Key to the Yeasts. Amsterdam: North Holland Publishing Co.

Buhagiar, R. W. M. \& Barnett, J. A. (1971). The yeasts of strawberries. Journal of Applied Bacteriology 34, 727-739.

CAMERON, R. E. (1971). Antarctic soil microbial and ecological investigations. In Research in the Antarctic, pp. 137-190. Edited by L. O. Quam \& H. D. Porter. Washington, D.C.: AAAS, publication no. 93.

Cameron, R. E. (1974). Application of low-latitude microbial ecology to high-latitude deserts. In Polar Deserts and Modern Man, pp. 71-90. Edited by T. L. Smiley \& J. H. Zumberge. Tucson: University of Arizona Press.

Collins, V. G. (1969). Isolation, cultivation and maintenance of autotrophs. Methods in Microbiology 3B, 1-52.

Dawes, E. A. (1976). Endogenous metabolism and the survival of starved prokaryotes. Symposia of the Society for General Microbiology 26, 1953.

di Menna, M. E. (1966). Yeasts in Antarctic soils. Antonie van Leeuwenhoek 32, 29-38.
Evison, L. M. \& Rose, A. H. (1965). A comparative study on the biochemical bases of the maximum temperature for growth of three psychrophilic micro-organisms. Journal of General Microbiology 40, 349-364.

Fell, J. W. (1974). Distribution of yeasts in the water masses of the southern oceans. In Effect of the Ocean Environment on Microbial Activities, pp. 510-523. Edited by R. R. Colwell \& R. Y. Morita. Baltimore: University Park Press.

Fell, J. W. \& Phaff, H. J. (1971). Genus F. Leucosporidium Fell, Statzell, Hunter et Phaff. In The Yeasts, A Taxonomic Study, 2nd edn, pp. 776802. Edited by J. Lodder. Amsterdam: North Holland Publishing Co.

FrIEDMANN, E. I. \& OCAMPo, R. (1976). Endolithic blue-green algae in the Dry Valleys: primary producers in the Antarctic desert ecosystem. Science 193, 1247-1249.

Goto, S., Sugiyama, J. \& Iizuka, H. (1969). A taxonomic study of Antarctic yeasts. Mycologia 61, 748-774.

Gregory, P. H. (1966). Dispersal. In The Fungi, An Advanced Treatise, vol. II, pp. 709-732. Edited by G. C. Ainsworth \& A. S. Sussman. New York : Academic Press.

GREGORY, P. H. (1973). The Microbiology of the Atmosphere, 2nd edn. New York: John Wiley.

Hagler, A. N. \& Lewis, M. J. (1974). Effect of glucose on thermal injury of yeast that may define 
the maximum temperature of growth. Journal of General Microbiology 80, 101-109.

Horowitz, N. H., Cameron, R. E. \& Hubbard, J. S. (1972). Microbiology of the dry valleys of Antarctica. Science 176, 242-245.

JANNASCH, H. W. (1967). Enrichment of aquatic bacteria in continuous culture. Archiv für Mikrobiologie 59, 165-173.

Kendrick, W. B. \& CARMichael, J. W. (1973). Hyphomycetes. In The Fungi, An Advanced Treatise, vol. IV A, pp. 323-509. Edited by G. C. Ainsworth, F. K. Sparrow \& A. S. Sussman. New York: Academic Press.

LeEs, H. \& QUASTEL, J. H. (1946). Biochemistry of nitrification in soil. Biochemical Journal 40, 803-815.

Matin, A. \& Veldkamp, H. (1978). Physiological basis of the selective advantages of a Spirillum $\mathrm{sp}$. in a carbon-limited environment. Journal of General Microbiology 105, 187-197.

MCGINNIs, M. H. (1974). Preparation of temporary or permanent mounts of microfungi with undisturbed conidia. Mycologia 66, 169-170.

Morita, R. Y. (1975). Psychrophilic bacteria. Bacteriological Reviews 39, 144-167.

PADY, S. M. (1974). Sporobolomycetaceae in Kansas. Mycologia 66, 333-338.

PhafF, H. J. \& Fell, J. W. (1971). Cryptococcus Kutzing emend. Phaff et Spencer. In The Yeasts, A Taxonomic Study, 2nd edn, pp. 1088-1091. Edited by J. Lodder. Amsterdam: North Holland Publishing Co.

PIANKA, E. R. (1976). Competition and niche theory. In Theoretical Ecology: Principles and Applications, pp. 114-141. Edited by R. M. May. Philadelphia: W. B. Saunders Co.

PIRT, S. J. (1975). Principles of Microbe and Cell Cultivation. New York: John Wiley.

RIDDELL, R. (1950). Permanent stained mycological preparations obtained by slide culture. Mycologia 42, 265-270.

StruHL, K. \& MagasaniK, B. (1976). Ammoniasensitive mutant of Klebsiella aerogenes. Journal of Bacteriology 126, 739-742.

Sussman, A. S. \& Halvorson, H. O. (1966). Spores. New York and London: Harper \& Row.

VishniaC, H. S. \& Hempfling, W. P. (1979). Cryptococcus vishniacii sp.nov., an Antarctic yeast. International Journal of Systematic Bacteriology (in the Press).

VishniaC, W. V. \& Mainzer, S. E. (1973). Antarctica as a Martian model. Cospar Life Sciences and Space Research XI, 25-31.

VishniaC, W. \& SANTER, M. (1957). The thiobacilli. Bacteriological Reviews 21, 195-213.

WAHLer, B. E. \& Wollenberger, A. (1958). Zur Bestimmung des Orthophosphats neben säuremolybdate-labilen Phosphorsäureverbindungen. Biochemische Zeitschrift 329, 508-520.

Watson, K., Arthur, H. \& Shipton, W. A. (1976). Leucosporidium yeasts: obligate psychrophiles which alter membrane-lipid and cytochrome composition with temperature. Journal of General Microbiology 97, 11-18.

Wolk, C. P. (1973). Physiology and cytological chemistry of blue-green algae. Bacteriological Reviews 37, 32-101. 